\author{
Romana Lekić, Nataša Mance \\ Tourism Department, Vern University of Applied Sciences, Zagreb, Croatia \\ Damir Herceg \\ Web Portalwww.udruga-stanara.hrdherceg@udruga-stanara.hr \\ UDC: 005.32:338.48
}

\title{
HOME SWAPPING - A NEW INTERNATIONAL TREND: EMOTIONS LEAD TO AN AUTHENTIC EXPERIENCE
}

\begin{abstract}
The hyper-consumption society expands in the name of happiness and tourism attracts masses. However, despite the production and consumption, we are gradually sinking deeper into the crisis of material cultural happiness. Tourism provides an answer to this race for higher production and material pleasures by creating the new focal points (interest centers) through new kinds of tourism: the special interest tourism and the trans-modern tourism. These new trends focus on responsible consumption as opposed to destructive consumption of mass tourism.

In this paper we point to the process of transformation in tourism: products and services which make up the basic tourist product are no more sufficient. New paradigms in tourism ap-
\end{abstract}

\section{Existential tourism: route to an authentic experience}

Tourism has for years followed the pattern of industry. Immediately after the discovery (in its modern form), tourist activities became the object of their own rules. Although mass tourism is still predominant, the current growth of alternative forms of tourism, among which 'home exchange' is on the rise, indicates that there are different consumer requirements and that these can be met. From that point of view, tourism has to renew its interest in people and place an pear under the wings of cultural globalization. In the economy of experience and gratitude, tourists have ceased buying a service. They buy experience which constitutes a memory and a sensation. By showing the example of a new global trend of home swapping (also: home exchange), we shall indicate the opportunity to involve the tourist in an individual way. It is a way of generating emotion and exchanging values, based on confidence between people, enabling a unique experience of atmosphere, travel, getting to know local culture and forging lasting friendship.

Key words: home swapping, hyper-consumption, transformation, trans-modern tourism, the economy of experience

individual in the centre of the entire system of tourism. There is a growing awareness of the need to develop better tourism, which will benefit all equally, treat everyone equally and share responsibility equally. Travellers of today are motivated by the wish to get familiar with a culture different from their own, in a place which cannot be replaced by another tourist destination. Hospitality in the real sense of the word allows for a certain degree of closeness of visitors and hosts, and get familiar with the natural and cultural environment of the destination. The essence of tourism is that the visitors seek social contact 
which is sincere and close, in a setting that is unusual and attractive. Travelling provides an escape from everyday life and the form of consuming happiness that we greatly miss in our everyday environment. Leaving to unknown parts is a personal fulfillment and a lasting new experience which can boost us for a long time.

We could say that home exchange is an activity which is undertaken out of the free will of an individual and his personal choice and motivation. There is no wish for material gain. In organized environment, we wish to travel differently and stay out of formal forms of accommodation, to get deeply familiar with the culture of Others thus contributing to common values. Home exchange should make possible for tourists to be more than observers and become real protagonists of their travel, establishing social contact with the local population. The exchange, since the tourist conveys his spirit and culture, enables better understanding between the two parties. Closeness that is thus created satisfies the needs that could be called 'existential tourism' (Dimanche and Ferry, 2003: 426-429).

This paper shows the significance of authenticity which drew the attention of philosophers and scientists. Embarking from the humanistic tradition and the theme of authenticity, we shall mention some theoretical works, and among the most relevant the essays by Heidegger (1927), Schuetz (1932), Adormo (1964), Berger and Lueckmann (1966). Since the 1970s, when MacCannell $(1973,1976)$ introduced the concept of authenticity in the studies of tourist motivation and experience, this topic has become very prominent and sparked off discussions in tourism-related research. A large number of theoretical and empirical works published since contributed to the development of the concept of authenticity, so let us mention a part of them here: Brunner (1994), Chhabra, Healy and Sills (2003), Cohen (1979, 1988), Cohen, Hattab and Kerber (2004), Crang
(1996), Daniel (1996), Golomb (1995), Harkin (1995), Hughes (1995), Kim and Jamal (2006), Littrel, Andersen and Brown (1993), Pearce and Moscardo (1985), Salamone (1997), Selwyn (1996), Stiner and Reisinger (2006), Taylor (2001), Waitt (2000), Wang (1999), Wang (2007), Wu (2002), Xie (2006), Zou and $\mathrm{Wu}$ (2003).

In the course of the 1970s a discussion was begun concerning ideas questioning the creation of an authentic social experience through tourism. Works of Pearce and Moscardo (1985), Olsen (2002), Chabra (2005) or Reisinger and Steiner (2006) gave a big contribution to this discussion, and it should be mentioned that Boorstin (1961) initiated a sociological debate on authenticity. Likewise, certain authors of very important critical essays on the significance of tourism and tourists shed light on this issue, such as Auge (1997), Baudrillard (1938), Eco (1986), Ritzer and Liska (1997).

The concept of authentic experience draws us into a long-standing philosophical tradition which interprets the significance of being a human, the meaning of happiness and being true to oneself. It is therefore important to mention the works of renown philosophers: Hegel (1977), Heidegger (1996), Kant (1929), Kierkegaard (1985), Rousseau (1979) and Sartre (1992). Kierkegaard, like Schelling, Nietzsche, and even Feuerbach and Marx, tried to bridge the dichotomy between reason and emotions, in the sociological sense, drawing the individual's attention to the reality of authentic experience which creates a backdrop for both the subjective and the objective. Being in touch with one's own inner being and having the knowledge and awareness of this being are an authenticity (Kierkegaard, 1970). In order to be authentic, people have to invent themselves as they would like to be. It is necessary that, from their own free will, they make a choice when they are faced with an opportunity to choose (Sartre, 1992). Being alert to one's own experience instead of interpreting the 
world through institutionalized concepts and abstractions makes people authentic individuals (Maslow, 1968; Heidegger, 1996).

\section{Networking on the internet: portals for home exchange (SWAP)}

Networking on the Internet, which enables home exchange while travelling, is called home exchange or home swap. In 1992, Ed Kushins from California established the Internet portal Homexchange.com and became the pioneer in home swapping. Today, this is the largest and the fastest growing portal for home exchange. In 2012, the members had more than 75000 exchanges in 150 countries. This portal is accessible in 15 languages. From June 2011, the Croatian branch is a member of the network, under the name 'Mijenjam vikendicu' (cottage exchange). By the end of May 2013, there were 114 exchange offers for Croatia. A new international page HomeExchangeGold was started recently, for luxury homes exchange. Almost all countries are a part of this network and its users communicate on daily basis and arrange exchanges on all continents. Apart from erasing financial obstacles to travel, home exchange opens a completely new dimension of travel and getting familiar and bonding with new cultures. Home exchange makes new, interesting friendships possible and offers a totally new experience of travel, inconceivable in the predictable hotel travel scheme. It is clear that exchanging homes with people one does not know at all requires a great deal of trust and respect for the home and culture of the host. According to information obtained from www. homeforexchange.com, users are usually highly educated, broad-minded people who like to travel. One of the pages has for nine years been edited by Ans Lammers from the Netherlands. Her portal has over 15000 members from all over the world, and they exchange houses, cottages, flats, even boats. The page is based on a simple principle: the user registers, pays a membership fee which is between 60 and 110 USA $\$$ for one, or, at most, three years, offers a flat or a house with a description and photos and posts the place and country he would like to travel to ${ }^{1}$. The interested members will send him e-mails and check whether there is interest in exchange. Once a month each member automatically gets potential houses/flats for exchange, according to the wishes expressed. The owner of the portal introduced insurance against cancellation in case of illness and other emergencies. This page and others like it promote the mission they share:

"We connect like-minded travellers, help them travel anywhere, live like locals, and stay for free. Our company spirit mirrors our service; we bring people together to share ideas, explore new concepts, and see the world-together."

By looking into the Internet home exchange portals, we get to a common denominator: a shared happiness, sharing and trust! All registered at home exchange so-

The advice and steps to be observed by home exchange portal members: 1) Put the best photos on their page 2) Put together a good description of their home in 300 to 500 words, indicating what makes your home special, together with the possible use of bicycle, swimming pool, garden, Internet access, etc. 3) Describe the surrounding area and make a list of local attractions, to help your exchange partners 4) Make a video-recording of your home 5) Be truthful in presenting your home 6) Register with one of the networks which will give you a user name and password, which protects your identity until you decide to share it with the exchange family 7) After the selection of the desired location, the exchange process consists of establishing a direct contact with the exchange partner and agreeing on dates and length of stay and signing the exchange agreement. 
cial networks take part supposing that everyone who participates is like themselves: open-minded, loving travel and getting to know other cultures and customs. Staying at a host's home, they will live as other people in that country do. In many cases, they will have an opportunity to meet family and friends of those they exchanged home with, and become a part of their society. It is a priceless experience which is lived deeply through new friendships. New, deeply emotional connections are made. The membership fee is symbolic, and the values that get exchanged are non-material: familiarizing with local culture, the experience of a place from a different, closer, non-tourist angle. Home exchange is a voluntary activity, which presupposes the freedom of choice, and freedom is the basic aspiration of the human civilization and the main feature of democracy. Plus, this form of travel contains the potential of creating economic gratitude and compassion and solidarity with others and different ones.

By analyzing blogs at the home exchange portals, we see that travel touches everyone and leaves no one indifferent, because everyone experiences emotions, memories, intimacy. Everyone carries in himself emotion experienced in the course of a trip, they enrich and determine an individual. When selecting a destination and visiting a place, tourists seek closeness: they want to see and know everything and feel a true bond. This wish makes it possible for a tourist to feel less of a stranger, even to feel a part of a tourist destination. If people, society and culture are awarded a central position, they cannot be discussed without considering their very essence. Human 'territory' is also where tourism takes place, it is its venue. People and their surroundings make a tourist destination. One cannot exist without another. (Dimanche and Ferry, 2003:426-429).

Further analysis of blogs can make us conclude that the real and the desired experience impact upon the hoped for expe- rience. It can also be influenced by personality, aspects of the trip and motivation for travelling. It is obvious that some tourists wanted new and different experiences: cultural tourists, for example, mostly sought to experience different cultures. Such motivation, among other, lead to a different experience of authenticity. Their need for the experience of different cultures encouraged them to look for 'typical' or 'authentic' aspects of a destination. In other words: they tried to get the experience of authenticity. They also wanted to get to know themselves through new activities and experience. They sought a certain kind of personal authenticity which can then be described as an authentic experience. For some travellers, the very journey was an authentic experience, because it was new and unique.

The blogs with experiences are particularly interesting, and the travel reports are charged with energy, emotion experienced and advice for other members of the network. Home exchange is the most authentic approach to a stay in a foreign country or culture. You can find yourself immersed in the exchange neighborhood or culture. You stand a good chance of meeting exchange neighbors, and the exchange local community. Likewise, you can discover new local shops, restaurants, parks, playgrounds, excursion sites, etc. This kind of travel offers a unique and realistic trip which can hardly be surpassed. The difference between consuming a home exchange package and that provided by a travel agency is infinite. "After a day's shopping and sightseeing, you come to a warm exchange home, sit in your favorite exchange armchair, have a hot bath and truly feel like having a holiday. There is enough time and space for your needs and for those of your family. You are not forced to stay in a confined space of a small hotel room, decorated without any imagination. You don't have to rush to a restaurant to heat your kid's bottle and can have a real family dinner, watch a film and enjoy each other's company, 
you can slow down, because you deserve it. Your children will enjoy the exchange toys, and there is always something for everyone: a favorite coffee mug, good bedtime reading, a film that you have not seen, or music you have not heard. There is a variety of possible enjoyments and experiences. In the meantime, your home is not empty, your mailbox is emptied and paper collected. Someone will water your flowers and houseplants, as if you were there. Your dog will happily bark in your yard, will get fed and walked regularly, as the exchange family will take care of everything, just as they do with their pets and their home. While you happily pass the time at your exchange destination, life will have its usual course at your home." ${ }^{2}$

Embarking from the mentioned ideas, home exchange travel can mean that a tourist trip can be a cure for an awkward loss of identity. The recognition of the phenomenon of existential authenticity creates an opportunity for ethical rethinking about why tourism is managed, why it is presented and sold in certain ways. The role of visitor changes from that of a consumer only to that of a partner and becomes productive, with awareness of the need for sustainability of tourist destinations. In tourism, experiences converge around a theme and are presented as a special mood-generator. A successful destination communicates powerful emotion $^{3}$. Leisure industry has been through various stages of development, providing entertainment and information and education, alongside it. Today, we can speak of the 'emotion-creating process', which happens through enrichment, fulfillment, healing, self-healing, self-discovery and self-connecting, and dealing with emotions is the result of a new stage of the society, often called the 'dream society'.

\section{From: www.HomeExchange.com}

3 Many families have kept their friendships and acquaintances for a long time after the exchange, communicating by e-mails and telephone.

\section{From the anthropological angle: home exchange as an invitation to a different journey}

The development of tourism started in the $19^{\text {th }}$ century and its leisure-oriented philosophy followed the development of technology, leading to its becoming a market for leisure and entertainment. The society of hyper-consumption expanded in the name of happiness and tourism is adopted by masses. However, despite the production and consumption, according to Lipovetsky (2008), we are sinking deeper into the crisis of materialistic culture of happiness. Environmentrelated fears grow, there is an outcry for a different kind of economic development, new religious movements and new spiritual aspirations appear.

The expansion of the Internet damaged the position and the status of authenticity of the narrative in tourism, as well as the division into the true and the false, reality and fiction. This change is reflected in the hyper-consuming society and is encouraged by the diversification of taste, aesthetics and lifestyle. A total turnabout is happening now: form the market determined by supply to the demand-driven market. Products last less and new models appear in ever shorter intervals. The objective is to strengthen the feeling of individualized consumption.

We have come from the stage of 'time of choice' to the stage of 'time of hyper-choice. Tourism is in the hyper-choice category. Consumption in tourism has become hyper-individualistic consumption. Certainly, the individualization of choice tourists have is caused by the weakening of the impact of class on the life of an individual, who is now liberated from the obligation to fit in the prefabricated lifestyle. The turbo-tourist wants to get it all, and to get this at once.

In his book 'The Paradoxical Happiness', Lipovetsky (2008) researches models which give answers to question of where we 
stand concerning satisfaction and happiness in our societies. The first of these models, called Penia, stresses the causative link between material affluence and the feeling of dissatisfaction. Material pleasure prevails over dissatisfaction, and black clouds accumulate elsewhere. Desire for material things is not what makes it tragic, it is the difficulties encountered in attitude towards oneself and others. The omnipotence of advertising in tourism, which is often given prominence, should not be overestimated. Advertising adapts to the sensitivity of the society, rather than imposes new ways. The tourist is fickle and distant, rather than mesmerized by the magic of advertisements.

The other model that has to be mentioned is Nemesis, the divine power that to ancient Greeks represented the principle of envy, the fourth figure that the author is dealing with in order to analyze the modern individual and the approaches that try to bring him closer to us. The question is whether modern societies bring conditions which make people more envious of the material status and affluence of others. It has been noticed that today, especially in tourism, the emotional consumption gained the upper hand over the status consumption. The fact that others own material possessions cannot inspire strong jealousy any more. Caring for one's own happiness is stronger than being happy because of the unhappiness of others.

In the world of consumerism tourism represents the 'sunny side of the street' we are all searching for. Some do it to escape their daily routines, some to replace it with a more beautiful living. A few succeed in it, and the attraction of the quest for balance and substituting work with rest and enjoyment is precisely in that. The question that comes up is how to achieve this if someone else dictates what we do, where we go, how we live?

The responsible and sustainable tourism is a reaction to the near-insane race for production and material pleasures, turned towards pleasure and immediate interests, indifferent to long-term consequences, to the lethal enterprise which causes pollution of the environment, the decay of biodiversity and global warming. In responsible tourism, the tourist is marked as a subject who should be informed and educated, because he is entrusted with a task of paramount importance: to save the planet by changing everyday habits. The principle of responsibility is a group category which concerns the producers of tourist experience and the consumers of such events.

New paradigm of trans-modern tourism $^{4}$ encourages questioning and critical spirit, and, as a considerable force of the future, tries to prevent that culture in tourism be completely swallowed by the realm of spectacle and consumer lightness. Home exchange represents a creative turning point, i.e., a new paradigm and a creative code which stands opposite the infinite economic development and the obsession with material wealth and promotes the concept of quality of living as the criterion for measuring progress. The mentioned creativity is expressed in the form of the economy of knowledge which shifts the emphasis from

According to Ghisi (2006), the very concept of transmodern implies that the best of modernity is kept while at the same time we go beyond it. Transmodernism is critical of modernism and postmodernism while at the same time drawing elements from each. In a way it is a return to some form of absolute 'logic' that goes beyond the Western ideology and tries to connect the human race to a new shared story, which can be called a global consciousness (Rifkin, 2005). The original meaning of the term transmodernism was actually coined by the Spanish philosopher and feminist Rosa Maria Rodriguez Magda in her essay "La Sonrisa de Saturno: Hacia una teoria transmoderna" (1989), in which she uses Hegelian logic whereby modernity, postmodernity and transmodernity form the dialectic triad that completes a process of thesis, antithesis and synthesis. 
material capital to non-material (intangible) assets. Such creative approach combines the rational and the intuitive and is more balanced - not as an illusion, but as an individual quest for happiness, and, as such, values innovation and individual creativity. Home exchange is search for individual identity and self-evaluation. Sometimes it requires hard work, effort and engaging in surpassing oneself, outside the box of consumer satisfaction, improving measures that enable the development of other tastes and passions, than consumption.

\section{Conclusion}

The world we live in is a global village of worn out ideas. Copies of copies are made, and new copies from these, forever. Somewhere ahead of us there is the unchartered territory, the untouched treasure which we have to discover first, and then present it to others, not only for the sake of profit, but for the joy of sharing. Tourism is the industry of happiness, the healing phenomenon where happiness is to make other happy, to give them the experience, but also the fulfillment of ourselves who have to live with it and finally enjoy our own creation and, if only briefly, experience what will make our lives better and prettier, but will do that for everyone around us, too. Being unselfish has to figure prominently on the list of our priorities, because it gives us inner peace and makes it easier to find ourselves in the course of life, if we eventually stay there. Tourism expects the guest who struggles with his own life and puts in enormous effort to make possible for himself the escape from toiling. Home exchange gives such tourist an experience that will erase the worse side of his life, will bring a smile to his face after he returns to work, thus whetting his appetite for more travel and discovering of new destinations.

The Internet home-exchange is a sort of transformation which Lipovetsky (2008) speaks of, a complex process of transformation of the object of consumer society of Western civilization into a structure and identity of man as the 'desire machine'. At the same time, it gives the opportunity to analyze the tourist-consumer on the path to the sublime self-determination of an individual. Home exchange creates an unforgettable experience and sensation and provokes sincere emotion and joie de vivre. This special feeling can be described by the term 'communitas' - coined by the anthropologist of symbols Victor Turner (1976). It denotes a powerful feeling of emotional bonding between participants in a ritual which overcomes differences between them and their social lives - it is a spontaneous and compassionate experience of camaraderie. In a tourist destination 'communitas' in its purest 'existential' form is the direct, immediate and complete confrontation of human identities which, when it happens, makes the ones who experienced it believe that humanity is a homogeneous, unstructured and free community.

\section{References}

Adorno, T. (1964). Jargon der Eigentlichkeit. Zur deutschen Ideologie. Frankfurt am Main, Suhrkamp

Alić, S. (2009). Mediji, od zavođenja do manipuliranja, AGM, Zagreb

Auge, M. (1997). L'impossible voyage. Le tourism et ses images, Paris, Rivages

Baudrillard, J. (1983). Simulations. New York, Semiotext(e

Berger, P.L. and Luckmann, T. (1966). The Social Construction of Reality: A Treatise its the Sociology of Knowledge. Garden City, New York: Anchor Books, pp. 51-55

Boorstin, D.J. (1961). America and the Image of Europe: Reflections on American Thought, Cleveland, World Publishing Co.192.pp

Bruner, E. M. (1994). Abraham Lincoln as authentic reproduction: a critique of post- 
modernism. American Anthropologist, 96, 397-415. 59-61.

Philadelphia, Temple University Press (2002) The Economist June 8.

Chhabra, D., (2005). Understanding VFR Markets and Their Economic Impacts. E-. Review of Tourism Research, 3 (4): 97-102

Chhabra, D. Healy, R. and Sills, E. (2003). Staged authenticity and heritage tourism. Annals of Tourism Research, 30(3), 702719

Cohen, E. (1979). A phenomenology of tourist experiences. Sociology, 13,179-201

Cohen, E. (1988). Authenticity and Commoditization in Tourism. Annals of Tourism Research 15:371-86.

Cohen-Hattab, K. and Kerber, J. (2004). Literature, cultural identity and the limits of authenticity: a composite approach. International Journal of Tourism Research, 6(2), 57-73

Crang, M. (1996). 'Living history : magic kingdoms or a quixotic quest for authenticity?', Annals of tourism research, 23 (2). pp. 415431

Daniel, Y. P. (1996). Tourism dance performances: authenticity and creativity. Annals of Tourism Research, 23(4), 780-797

Dimanche, F. and Ferry, M. (2003). Shaping tourism destinations: Back to the basics. Tourism

Eco, U. (1986). Travels in hyperreality. London: Picador

Ghisi, L.M. (2006). Transmodernity and transmodern tourism. A keynote presented at the 15th Nordic Symposium in Tourism and Hospitality Research: Visions of Modern Transmodern Tourism, Savonlinna, Finland, 19.22 October

Golomb, J., (1995). In search of authenticity. London: Routledge

Harkin, M., (1995). Modernist anthropology and tourism of the authentic. Annals of Tourism Research, 22(3), 650-670.

Hegel, G., (1977). Phenomenology of Spirit, Oxford: Clarendon press
Heidegger, M. (1996). An Introduction to Metaphysics, New Haven: Yale, University Press.

http://www.nn.hr/sluzbeni-list/mugovori/index.asp (pristupljeno 9.6.2006.)

Hughes, G. (1995). Authenticity in tourism. Annals of Tourism Research, 22(4), 781803

Kant, I. (1929). Critique of Pure Reason, New York, Macmillan

Kierkegaard (1970). Pojam strepnje, preveo Gligorije Ernjaković, Srpska književna zadruga, Beograd

Kim, H. and Jamal, T. (2006). Touristic quest for existential authenticity. Annals of Tourism Research, 34(1), 181-201

Lipovetsky, G., (2008). Paradoksalna sreća - Ogled o hiperpotrošačkom društvu, Izdanja Antibarbarus, Zagreb

Littrell, M. A., Andersen, L. F. and Brown, P. J. (1993). What makes a craft souvenir authentic? Annals of Tourism Research, 20(1), 197-215

MacCannell, D. (1973). Staged authenticity: arrangements of social space in tourist settings. American Journal of Sociology, 79, 589-603

MacCannell, D. (1976). The Tourist: A New Theory of the Leisure Class, Schocken Books, University of California Press

Magda, R.M.R. (1989). Transmodernity. Online essay. On WWW at http://es.geocities. com/circulocero/magda.html (pristupljeno 15.01.2011.)

Maslow, A. (1968). Toward a Psychology of Being (Second ed.) Princeton: Van Nostran

Olsen, K. (2002). Authenticity as a concept in tourism research. The social organization of the experience of authenticity. Tourist Studies 2(2), 159-182

Simpson, J. and Weiner, E., (eds.) (1989). The Oxford English Dictionary, Second Edition, Clarendon Press, 21,728 pages

Pearce, P. L. and Moscardo, G. M. (1985). The relationship between travellers' career levels and the concept of authenticity. Australian journal of Psychology, 37(2),157-174. 
Reisinger, Y. and Steiner, C.J. (2006). Reconceptualizing object authenticity. Annals of Tourism Research 33(1), 65-86

Rifkin, J. (2005). The European Dream: How Europe's Vision of the Future is Quietly Eclipsing the American Dream. New York: Penguin Group.

Ritzer, G. and Liska, A. (1997). MacDisneyizationand Post-Tourism: complementary perspectives on contemporary tourism. In C. Rojek i J. Urry (eds.), Touring Culture. London: Routledge

Rousseau, J.J. (1979). Emile or On Education, Alan Bloom. New York: Basic Books

Salamone, F. A. (1997). Authenticity in tourism: the San Angel inns. Annals of Tourism Research, 24(2), 305-321

Sartre, J.-P. (1992). Being and Nothingness, New York: Simon i Schuster

Schuetz, A. (1932). Der sinnhafte Aufbau der sozialen Welt: eine Einleitung in die verstehende Soziologie. Wien: J. Springe

Selwyn, T. (1996). The tourist image: myths and myth making in tourism. Chichester: Wiley

Stiner, C. J. and Reisinger, Y. (2006). Understanding existential authenticity. Annals of Tourism Research, 33(2), 299-318.
Taylor, J. P. (2001). Authenticity and sincerity in tourism. Annals of Tourism Research, 28(1), 7-26

Turner, V. (1976). Ritual, Tribal and Catholic. Workship, 50(6), 504-524

Waitt, G. (2000). Consuming heritage: perceived historical authenticity. Annals of Tourism Research, 27(4), 835-862.

Wang, N. (1999). Rethinking Authenticity in Tourism Experience, Annals of Tourism Research, vol. 26, no. 2, pp. 349 - 370.

Wang, Y. (2007). Customized authenticity begins at home. Annals of Tourism Research, 34(3), 789-804

$\mathrm{Wu}, \mathrm{Z}$. (2002). A study in authenticity and performance of cultures in tourism activities. Tourism Science, 16(2), 7-9.

Xie, Y. (2006). On tourism experience: a perspective of phenomenology. Tianjin: Nankai University Press.

Zou, T. and Wu, L. (2003). The nature and categories of tourism experiences and developing principles. Tourism Science, 17(4), 7-9. www. homeexchange.com www. homeforexchange.com 
